INDEPENDENT JOURNAL OF MANAGEMENT \& PRODUCTION (IJM\&P)

\title{
AN APPLICATION OF FULL COST ASSESSMENT IN THE ENERGY SECTOR
}

Denise Helena Lombardo Ferreira Pontifícia Universidade Católica de Campinas, Brazil

E-mail: lombardo@puc-campinas.edu.br

Carolina Baron Pontifícia Universidade Católica de Campinas, Brazil E-mail: carolbaron94@gmail.com

Luciano Hideaki Fujita Pontifícia Universidade Católica de Campinas, Brazil E-mail: luciano.hf@puccampinas.edu.br

Submission: $16 / 02 / 2016$ ABSTRACT

Accept: 22/03/2016

This article seeks to evaluate some plants for electricity generation existing in Brazil, among which wind, thermal, hydroelectric and nuclear power, through the Full Cost Assessment tool. Two studies were prepared, the first deals with the analysis of these plants in view of the technical-economic, environmental and social factors. The second study is the analysis of these plants in view of the cost of energy and energy production in the five Brazilian regions - South, Southeast, Midwest, North and Northeast. The final results show that in the first study the wind farm had the highest valuation, so the best option among the others. However, the second study, wind power was the one that obtained the highest valuation for the Northeast Region, and the thermoelectric and hydroelectric plants had the highest valuation for the Southeast Region.

Keywords: Full Cost Assessment; electricity; Brazilian regions 


\section{INTRODUCTION}

For decades, especially since the industrialization period, human activity is impacting the ecosystem and its environmental resources. Currently the world is going through a period in which the human being is placed as the center of everything, often causing an unsustainable environment. The concern focuses on quick and easy economic gain without regard to preserving the environment.

As stated by Hawken, Lovis and Lovis (2007), the process of production and mass consumption in the world today and factors arising as rapid industrialization, spatial concentration, agricultural modernization, significant population growth and increasing urbanization, climate change, depletion of productive resources, water scarcity, pollution of soil water and air, make up the main points of pressure and human awareness of global environmental issues.

The worsening environmental situation demand studies and the development of alternative proposals to overcome the contradictions of the present world scenario, being prudent to search for methods that preserve natural resources, which often requires the need to make decisions from the simplest to the most complex.

The development of a model representing reality can help in choosing the most appropriate decisions. Mathematical models use mathematical relationships to describe or represent an object or decision problem, and may, in his creative process, assist in the understanding of the problem, and as a result improve decision analysis.

In order to evaluate some plants for electric power generation that exist in Brazil, this paper makes use of a tool that helps in the process of decision making, called Full Cost Assessment (FCA) to two distinct problems. One considers the four types of power plants for electricity generation treated here in view of the environmental factors, technical- economic and social. The other problem analyzes these plants for electric power generation among the five Brazilian regions taking into account the parameters of cost and energy production.

The results show that wind energy appears as 1st choice followed by nuclear, hydro and thermal power in the application of FCA in the evaluation of these four plants for electric power generation in view of the environmental factors, technicaleconomic and social. Regarding the application of this tool in the study of these 
DOI: 10.14807/ijmp.v7i3.438

plants for the five Brazilian regions for the cost of energy production the conclusion is that the wind farm has the highest valuation for the Northeast, while the thermoelectric and hydroelectric plants have the highest valuation for Southeast region.

\section{MATERIALS AND METHODS}

The Full Cost Assessment tool is based on the identification and assessment of data on external impacts and costs / benefits of the activities in question.

The FCA tool was initially developed to account for the costs arising from environmental impacts of an enterprise (Burani et al., 2004). Later, according to Carvalho (2000), this concept was used to account for all costs related to the project, such as social, political and environmental factors.

In traditional assessments, normally, an economic evaluation (mainly considering the internal costs) is done at which the environmental costs, social, cultural are not considered or when considered, are delegated to the background. This form of assessment is inconsistent within an integrated resource planning, since upon disregarding the external costs, one can get to the selection of a particular resource that is not the most appropriate (Burani et al., 2004).

Regarding the power generation subject, to Boarati (2003) the FCA tool revolutionizes the way of evaluating the feasibility of a plant, for they were usually considered only aspects related to the investment, the plant's construction and its financial return, however, it is required to take into account other related factors on the venture feasibility. As pointed out by Gimenes et al. (2004), through the FCA some variables needed for decision-making can be identified and addressed, directing the application of methodologies for sustainable development and resource planning by providing treatment to elements that traditionally do not take part in the planning.

The FCA tool makes it possible to analyze the technical-economic factors, environmental, social and political with the same importance. The factors necessary for a decision-making process can be identified and addressed in order to satisfy the concepts of sustainable development and resource planning. 
DOI: 10.14807/ijmp.v7i3.438

Through FCA different analysis elements are valued from two types of weighting: 1) alternatives to each element under analysis and 2) the weight of each element under analysis. According Boarati (2003), these two criteria enable each analysis element to be evaluated according to the available options. The alternatives are considered by percentages, ranging from the best (100\%) to the worst alternative (25\%), with the following classification: excellent (100\%), satisfactory $(75 \%)$, regular $(50 \%)$ and unsatisfactory (25\%). The weight of each element of analysis varies between $A, B, C$, in descending order of importance.

Given that the factors considered must have the same importance, the maximum valuation for all of them is 100 points according to Eq. 1 .

$$
\mathrm{X}(\mathrm{A})+\mathrm{Y}(B)+\mathrm{Z}(C)=100
$$

Where:

A, B and C are variations of each Analysis Element - depends on the importance attached to the Analysis Element within the considered factor, being $A=$ maximum importance $(A=300), B=2 / 3$ of the maximum importance $(B=200)$ and $C=1 / 3$ of the maximum value $(C=100)$;

$\mathrm{X}, \mathrm{Y}$ and $\mathrm{Z}$ are the numbers of occurrences of the Analysis Elements with the rating A, B or C, respectively.

From the definition of the Analysis Elements and their respective weights (A, B or C) is made the calculation of KFC given by Eq. 2 .

$$
\mathrm{KFC}=\frac{\mathrm{X}(300)+\mathrm{Y}(200)+\mathrm{Z}(100)}{100}=\mathrm{X}(3)+\mathrm{Y}(2)+Z(1)
$$

Where:

KFC is the Constant of the Considered Factor.

A Eq. 3 shows $\mathrm{VEA}_{i}$ calculation

$$
\mathrm{VEA}_{\mathrm{i}}=\left\{\frac{\text { weight }(\mathrm{A}, \mathrm{B}, \mathrm{C})}{\mathrm{KFC}}\right\} * \text { alternative }
$$


Where:

$V_{E A}$ é is the valuation of Analysis Element $i$.

Lastly Eq 4 is obtained.

$$
\mathrm{VF}=\sum \mathrm{VEA}_{\mathrm{i}}
$$

Where:

VF is the Factor Valuation.

Table 1: Numeric Example of Full Cost Assessment.

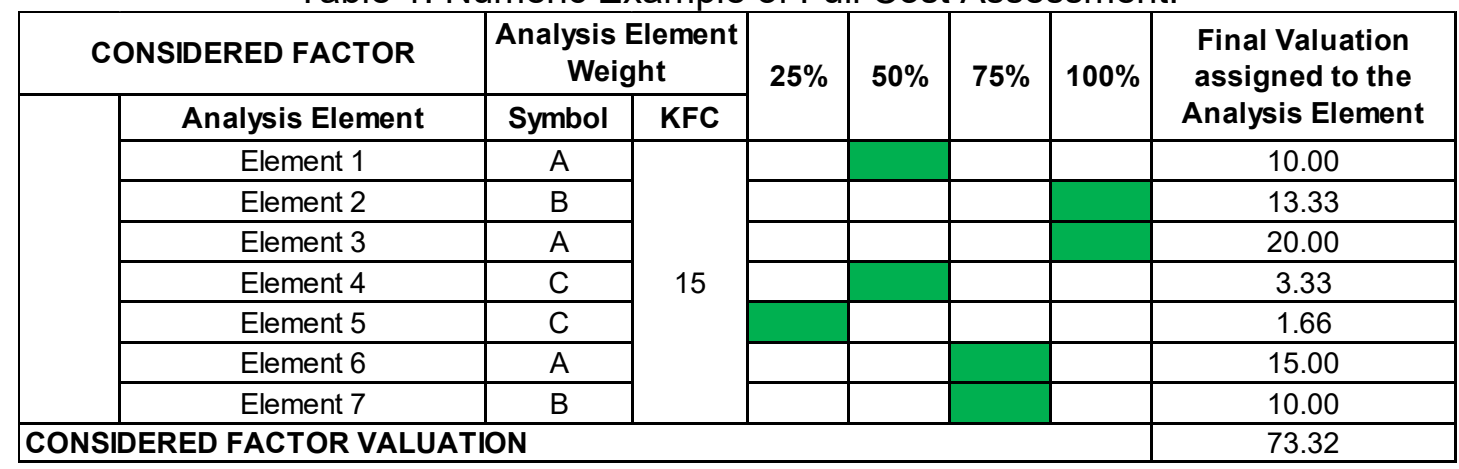

Source: based in Bachi Junior, Tiago Filho e Seydell (2013).

The filled in cells at Table 1 presents the options selected according to the research on this topic (BACHI JUNIOR; TIAGO FILHO; SEYDELL, 2013).

In the numeric example of Table 1 , the value of the KFC is $15(3 * 3+2 * 2+$ 2), because there are three analysis elements with Valuation $A$, two analysis elements with Valuation B and two analysis elements with Valuation $\mathrm{C}$. It is highlighted the calculation made for the Valuation Analysis Element 1 (Eq. 5).

$$
V E A_{1}=\left(\frac{300}{15}\right) * 50 \%=10,00
$$

\section{RESULTS}

The section in question presents the results obtained in the application of FCA for the two studies mentioned above.

3.1. FCA application in the analysis of power plants considering the environmental factors, technical-economic and social 
DOI: $10.14807 /$ ijmp.v7i3.438

The application of FCA is made to analyze the feasibility of using four plants of electricity generation in Brazil, namely, wind, hydroelectric, thermal and nuclear. An analysis considered traditional uses only technical and economic elements for the viability of an enterprise. However, it is interesting to take into account not just one factor, but three factors that are of great importance to an alleged decision making: technical, economic, environmental and social as Rutherford (1997).

According to Boarati (2003), the technical and economic factors reflects the vision of the entrepreneur and investor to seek return of their invested capital through the sale of energy to be produced by the plant that must operate in a defined period of time.

The environmental factor is the vision of the official agencies and environmental protection agencies (Boarati, 2003). Therefore, for the viability of the power plants is only possible if there is no opposition of these agencies, in other words, that the project in question does not degrade the environment.

The social factor is characterized by the population affected due to construction of the plants (Boarati, 2003). The installation of the plant causes many impacts on local society. Impacts related to the emission of pollutants or else dysfunction in local economic activities such as fishing, agriculture and tourism, causing population displacement due to the poor quality of living locally.

The central idea of the Full Cost Assessment in relation to energy resources in Brazil is studying the possibility of building and installation of power plants, in addition to analyzing the best investment option. For this, twelve tables were built following the model of Table 1, four for each factor (environmental, technical-economic and social). And, from these four, one table for each plant type (wind, nuclear, hydroelectric, thermoelectric).

For example, the following are the engineered tables for the power plant to the environmental factor (Table 2), technical-economic factors (Table 3 ) and the social factor (Table 4), with their respective analysis elements. 
INDEPENDENT JOURNAL OF MANAGEMENT \& PRODUCTION (IJM\&P)

http://www.ijmp.jor.br

v. 7, n. 3, July - September 2016

ISSN: 2236-269X

DOI: 10.14807/ijmp.v7i3.438

Table 2: Hydroelectric Power Plant evaluated by the environmental factor.

\begin{tabular}{|c|c|c|c|c|c|c|c|}
\hline Environmental Factor - Hydroelectric Plant & \multicolumn{2}{|c|}{$\begin{array}{c}\text { Analysis } \\
\text { Element Weight }\end{array}$} & \multirow{2}{*}{$\begin{array}{c}\text { Unsatisfactory } \\
\text { Alternative } \\
(25 \%)\end{array}$} & \multirow{2}{*}{$\begin{array}{c}\text { Regular } \\
\text { Alternative } \\
(50 \%)\end{array}$} & \multirow{2}{*}{$\begin{array}{l}\text { Satisfactory } \\
\text { Alternative } \\
(75 \%)\end{array}$} & \multirow{2}{*}{$\begin{array}{c}\text { Best } \\
\text { Alternative } \\
(100 \%)\end{array}$} & \multirow{2}{*}{$\begin{array}{l}\text { Final Valuation } \\
\text { attributed to the } \\
\text { Hydroelectric } \\
\text { Plant }\end{array}$} \\
\hline Analysis Element & Symbol & KFC & & & & & \\
\hline Fauna Degradation & B & \multirow{7}{*}{17} & $\begin{array}{l}\text { Greatly affects the } \\
\text { fauna }\end{array}$ & $\begin{array}{l}\text { Affects the } \\
\text { Sauna }\end{array}$ & $\begin{array}{l}\text { Little effect on } \\
\text { the fauna }\end{array}$ & $\begin{array}{c}\text { No effect on the } \\
\text { fauna }\end{array}$ & 2.94 \\
\hline Noise Pollution & B & & $\begin{array}{c}\text { Emits many } \\
\text { noises }\end{array}$ & Emits noises & Emits little noise & $\begin{array}{l}\text { It does not emit } \\
\text { noise }\end{array}$ & 5.88 \\
\hline Atmospheric Pollution & A & & $\begin{array}{c}\mathrm{SO}_{\mathrm{x}} \text { Emission and } \\
\mathrm{CO}_{2} \text { in saturated } \\
\text { areas }\end{array}$ & $\begin{array}{c}\mathrm{CO}_{2} \text { Emission } \\
\text { in saturated } \\
\text { areas }\end{array}$ & $\begin{array}{l}\mathrm{CO}_{2} \text { emissions } \\
\text { in small } \\
\text { quantities in } \\
\text { saturated areas }\end{array}$ & $\begin{array}{l}\text { It does not } \\
\text { pollute or emit } \\
\mathrm{CO}_{2} \text { in } \\
\text { unsaturated } \\
\text { areas }\end{array}$ & 17.64 \\
\hline Water Pollution & A & & Very High & High & Reasonable & Non Existing & 4.41 \\
\hline Ease of Obtaining License & C & & Many obstacles & $\begin{array}{c}\text { Reasonable } \\
\text { obstacles }\end{array}$ & Few obstacles & No obstacles & 1.47 \\
\hline Generation of Solid Waste & A & & $\begin{array}{l}\text { It produces many } \\
\text { waste }\end{array}$ & $\begin{array}{c}\text { It produces } \\
\text { reasonable } \\
\text { waste }\end{array}$ & $\begin{array}{l}\text { It produces few } \\
\text { waste }\end{array}$ & $\begin{array}{l}\text { It produces no } \\
\text { waste }\end{array}$ & 13.23 \\
\hline Ground Pollution & A & & $\begin{array}{l}\text { Harmful waste in } \\
\text { the soil, land } \\
\text { changes }\end{array}$ & $\begin{array}{l}\text { Affects soil } \\
\text { quality }\end{array}$ & $\begin{array}{l}\text { Affects slightly } \\
\text { the soil quality }\end{array}$ & $\begin{array}{l}\text { It does not } \\
\text { affects soil } \\
\text { quality }\end{array}$ & 13.23 \\
\hline \multicolumn{7}{|c|}{ HYDROELECTRIC POWER PLANTS ENVIRONMENTAL FACTOR TOTAL SCORE } & 58.80 \\
\hline
\end{tabular}

Source: author's elaboration.

Table 3: Hydroelectric Power Plant evaluated by the technical-economic factor.

\begin{tabular}{|c|c|c|c|c|c|c|c|}
\hline Technical-Economic Factor - Hydroelectric Plant & \multicolumn{2}{|c|}{$\begin{array}{c}\text { Analysis } \\
\text { Element Weight }\end{array}$} & \multirow{2}{*}{$\begin{array}{c}\text { Unsatisfactory } \\
\text { Alternative } \\
(25 \%)\end{array}$} & \multirow{2}{*}{$\begin{array}{l}\text { Regular } \\
\text { Alternative } \\
(\mathbf{5 0 \% )}\end{array}$} & \multirow{2}{*}{$\begin{array}{l}\text { Satisfactory } \\
\text { Alternative } \\
\quad(75 \%)\end{array}$} & \multirow{2}{*}{$\begin{array}{c}\text { Best } \\
\text { Alternative } \\
(100 \%)\end{array}$} & \multirow{2}{*}{$\begin{array}{l}\text { Final Valuation } \\
\text { attributed to the } \\
\text { Hydroelectric } \\
\text { Plant }\end{array}$} \\
\hline Analysis Element & Symbol & KFC & & & & & \\
\hline Energy Cost US\$/MW [1] & A & \multirow{5}{*}{11} & $>50$ & 40 a 50 & 30 a 40 & $<29$ & 20.45 \\
\hline Annual Production MWh [2] & B & & > 12 Millions & 7 a 12 Millions & 2 a 7 Millions & $<2$ Millions & 4.54 \\
\hline Construction Lead Time [3] & C & & $>6$ & 4 a 6 Years & 2 a 4 Years & $<2$ Years & 4.54 \\
\hline Maintenance Cost [4] & $A$ & & Very High & High & Median & Low & 27.27 \\
\hline Payback [5] & B & & $>12$ Years & 8 a 12 Years & 2 a 7 Years & $<2$ Years & 4.54 \\
\hline
\end{tabular}

Source: author's elaboration. 
INDEPENDENT JOURNAL OF MANAGEMENT \& PRODUCTION (IJM\&P)

http://www.ijmp.jor.br

v. 7, n. 3, July - September 2016

ISSN: 2236-269X

DOI: 10.14807/ijmp.v7i3.438

Table 4: Hydroelectric Power Plant evaluated by the social factor.

\begin{tabular}{|c|c|c|c|c|c|c|c|}
\hline Social Factor - Hydroelectric Plant & \multicolumn{2}{|c|}{$\begin{array}{c}\text { Analysis } \\
\text { Element Weight }\end{array}$} & \multirow{2}{*}{$\begin{array}{c}\text { Unsatisfactory } \\
\text { Alternative } \\
(25 \%)\end{array}$} & \multirow{2}{*}{$\begin{array}{c}\text { Regular } \\
\text { Alternative } \\
\quad(50 \%)\end{array}$} & \multirow{2}{*}{$\begin{array}{l}\text { Satisfactory } \\
\text { Alternative } \\
\text { (75\%) }\end{array}$} & \multirow{2}{*}{$\begin{array}{c}\text { Best } \\
\text { Alternative } \\
(100 \%)\end{array}$} & \multirow{2}{*}{$\begin{array}{l}\text { Final Valuation } \\
\text { attributed to the } \\
\text { Hydroelectric } \\
\text { Plant }\end{array}$} \\
\hline Elemento de Análise & Símbolo & KFC & & & & & \\
\hline Job Positions Creation & A & \multirow{5}{*}{12} & $\begin{array}{c}\text { No creation of } \\
\text { direct and indirect } \\
\text { job positions }\end{array}$ & $\begin{array}{l}\text { Low creation of } \\
\text { direct and } \\
\text { indirect job } \\
\text { positions }\end{array}$ & $\begin{array}{l}\text { Median creation } \\
\text { of direct and } \\
\text { indirect job } \\
\text { positions }\end{array}$ & $\begin{array}{l}\text { High creation of } \\
\text { direct and } \\
\text { indirect job } \\
\text { positions }\end{array}$ & 8.33 \\
\hline Project Location & A & & $\begin{array}{c}\text { Central area with } \\
\text { high population } \\
\text { density }\end{array}$ & $\begin{array}{l}\text { Peripheral area } \\
\text { with median } \\
\text { population } \\
\text { density }\end{array}$ & $\begin{array}{l}\text { Area in remote } \\
\text { locations with } \\
\text { low population } \\
\text { density }\end{array}$ & $\begin{array}{c}\text { Industrial areas } \\
\text { in remote } \\
\text { locations with } \\
\text { low population } \\
\text { density }\end{array}$ & 18.75 \\
\hline $\begin{array}{l}\text { Local Infrasctructure } \\
\text { Development }\end{array}$ & B & & No impact & Low Contribution & $\begin{array}{c}\text { Median } \\
\text { Contribution }\end{array}$ & $\begin{array}{c}\text { High } \\
\text { Contribution }\end{array}$ & 12.50 \\
\hline $\begin{array}{l}\text { Effects of environmental } \\
\text { imbalance in the social } \\
\text { environment (air and noise } \\
\text { pollution) }\end{array}$ & A & & $\begin{array}{c}\text { Emissions of SOx } \\
\text { and } \mathrm{CO}_{2} \text { in } \\
\text { saturated areas } \\
\text { and } \\
\text { noncompliance } \\
\text { with sound } \\
\text { legislation }\end{array}$ & $\begin{array}{c}\mathrm{CO}_{2} \text { emission in } \\
\text { saturated areas } \\
\text { and partial } \\
\text { compliance to } \\
\text { sound legislation }\end{array}$ & $\begin{array}{c}\mathrm{CO}_{2} \text { emission in } \\
\text { small amounts in } \\
\text { saturated areas } \\
\text { and compliance } \\
\text { to sound } \\
\text { legislation }\end{array}$ & $\begin{array}{l}\text { No emission of } \\
\qquad \mathrm{CO}_{2} \text { in } \\
\text { unsaturated } \\
\text { areas and } \\
\text { compliance to } \\
\text { sound legislation }\end{array}$ & 25.00 \\
\hline Contribution to Quality of Life & C & & & $\begin{array}{l}\text { There is no } \\
\text { significant } \\
\text { change }\end{array}$ & $\begin{array}{l}\text { reasonably } \\
\text { improves quality } \\
\text { of life }\end{array}$ & $\begin{array}{l}\text { Improves the } \\
\text { quality of life }\end{array}$ & 4.16 \\
\hline \multicolumn{7}{|c|}{ HYDROELECTRIC POWER PLANTS SOCIAL FACTOR TOTAL SCORE } & 68.74 \\
\hline
\end{tabular}

Source: author's elaboration.

Following the same model, tables for wind power plants, nuclear and thermal power were built. The total scores are depicted in Table 5.

Table 5: Final Valuation Results for each factor for the Power Plants.

\begin{tabular}{|c|c|c|c|c|}
\hline PLANT & NUCLEAR & WIND & THERMOELECTRIC & HYDROELECTRIC \\
\hline ENVIRONMENTAL FACTOR & 72.03 & 77.91 & 61.74 & 58.8 \\
\hline TECHNICAL-ECONOMIC FACTOR & 43.16 & 79.53 & 65.88 & 61.34 \\
\hline SOCIAL FACTOR & 79.16 & 72.91 & 58.32 & 68.74 \\
\hline TOTAL & 194.35 & 230.35 & 185.94 & 188.88 \\
\hline
\end{tabular}

Source: author's elaboration.

The scores shown in Table 5 indicate that, regarding the environmental factors, the best investment option is the wind farm, with the highest valuation of 77.91. For the technical-economic factor, the wind farm is also the most viable option, because of its score of 79.53. But, In relation to the social factor, the plant with the best valuation is the nuclear power plant, with 79.16.

So, to the end result, one can draw up a preliminary ranking of energy resources obtained in Brazil, 1st option: wind, 2nd option: nuclear, 3rd option: hydroelectric and 4th option: thermoelectric.

\subsection{FAC application in the analysis of power plants in the Brazilian regions}


DOI: 10.14807/ijmp.v7i3.438

The application of FAC is made to analyze the plants for power generation: wind, hydroelectric, thermal and nuclear in five regions of Brazil.

The Analysis Elements considered in this study are only cost and energy production. It is worth noting that data on the costs of each type of energy for each region were not found and therefore these values were estimated considering that the cost of energy is inversely proportional to its production.

Table 6 presents the scores obtained for the nuclear power plant in the Southeast. It is worth noting that the analysis of this plant was made only in this region since Brazil has this plant only in Angra dos Reis, State of Rio de Janeiro.

Table 6: Nuclear Plant - Southeast Region.

\begin{tabular}{|c|c|c|c|c|c|c|c|}
\hline SOUTHEAST REGION & \multicolumn{2}{|c|}{$\begin{array}{c}\text { Analysis Element } \\
\text { Weight }\end{array}$} & \multirow{2}{*}{$\begin{array}{c}\text { Unsatisfactory } \\
\text { Alternative } \\
(25 \%)\end{array}$} & \multirow{2}{*}{$\begin{array}{c}\text { Regular } \\
\text { Alternative } \\
(50 \%)\end{array}$} & \multirow{2}{*}{$\begin{array}{l}\text { Satisfactory } \\
\text { Alternative } \\
\quad(75 \%)\end{array}$} & \multirow{2}{*}{$\begin{array}{c}\text { Best } \\
\text { Alternative } \\
(100 \%)\end{array}$} & \multirow{2}{*}{$\begin{array}{c}\text { Final Valuation } \\
\text { attributed to } \\
\text { Southeast } \\
\text { Region }\end{array}$} \\
\hline ANALYSIS ELEMENT & Symbol & KFC & & & & & \\
\hline Energy Cost US $\$ / M W$ & B & \multirow{2}{*}{5} & Low & Medium & High & Very High & 10.00 \\
\hline Energy Production & A & & Low & Medium & High & Very High & 60.00 \\
\hline \multicolumn{7}{|c|}{ TOTAL SCORE FOR SOUTHEAST REGION - NUCLEAR PLANT } & 70.00 \\
\hline
\end{tabular}

Source: author's elaboration.

Similarly it was built tables for other plants and regions of Brazil. Table 7 summarizes the values obtained for each one of them.

Table 7: Final Valuation Plant/Region.

\begin{tabular}{|c|c|c|c|c|c|}
\hline PLANTS/REGIONS & SOUTH & SOUTHEAST & MIDWEST & NORTH & NORTHEAST \\
\hline NUCLEAR & 0.00 & 70.00 & 0.00 & 0.00 & 0.00 \\
\hline WIND & 65.00 & 65.00 & 45.00 & 50.00 & 70.00 \\
\hline THERMOELECTRIC & 50.00 & 70.00 & 45.00 & 65.00 & 50.00 \\
\hline HIDROELECTRIC & 65.00 & 70.00 & 50.00 & 45.00 & 45.00 \\
\hline
\end{tabular}

By comparing the four plants studied among the five regions of Brazil it is possible to determine, in each case, the most viable option for a possible investment.

As can be observed, it was not possible to analyze the feasibility of nuclear power among all regions as this type of Plant is only found in the Southeast. But, compared to other active plants in the regions it can be seen that the Southeast region had a high valuation so, we can consider it as a good investment option. On the other hand, the wind farm proved to be the most advisable for the Northeast region. While the thermoelectric and hydroelectric plants had a higher valuation for the Southeast region. 
DOI: 10.14807/ijmp.v7i3.438

\section{CONCLUSIONS}

The application of FCA in the first study shows that wind energy appears as 1 st choice, followed by nuclear energy, hydroelectric and thermal.

The application of FCA in the second study allows to conclude that the wind farm has the highest valuation for the Northeast, while the thermoelectric and hydroelectric plants have the highest valuation for the Southeast region.

Note that the FCA tool makes it possible to analyze several factors: environmental, social, political, technical and economical with the same importance. However, in the first study, it was not considered the political factor in view of the difficulty in obtaining data. In the second study, by emphasizing the study of plants for electricity generation in different regions of the country, it was decided to only address the cost and energy production, again because of the difficulty in obtaining information regarding the environmental, social, political and technical and economic these plants for each region of Brazil.

The user-friendly handling with the calculations made by Microsoft Excel tool enables the application of FCA in several areas. However, in the study presented, as previously mentioned, the greatest difficulty was in getting the data.

\section{REFERENCES}

BACHI JUNIOR; TIAGO FILHO, D. G. L.; SEYDELL, M. R. R. (2013). Um modelo de análise do transporte de derivados de petróleo através dos custos completos. Anais do V Congresso Brasileiro de Energia. Itajubá.

BOARATI, J. R. (2003). Um modelo para avaliação ponderada da hidreletricidade e termeletricidade com gás natural através dos custos completos. Dissertação (Mestrado) - EDUSP, São Paulo.

BURANI, G. F.; UDAETA, M. E. M.; FUJJI, R. J.; GALVÃO, L. C. R. (2004). O cenário dos recursos energéticos distribuídos no estado de São Paulo. Anais do $5^{\circ}$. Encontro de energia no meio Rural e Geração Distribuída.

CARVALHO, E. C. (2000). A Análise do ciclo de vida e os custos completos no planejamento energético. Dissertação (Mestrado) - EDUSP, São Paulo, 228 p.

GIMENES, A. L. V.; UDAETA, M. E. M; GALVÃO, L. C. R.; REIS, L. B. (2004). Modelo de Integração de recursos para um planejamento energético integrado e sustentável. X Congresso Brasileiro de Energia, Rio de Janeiro.

HAWKEN, P.; LOVINS, A.; LOVINS, H. (2007). Capitalismo Natural: criando a próxima revolução industrial. São Paulo: Cultrix. 
INDEPENDENT JOURNAL OF MANAGEMENT \& PRODUCTION (IJM\&P)

http://www.ijmp.jor.br

v. 7, n. 3, July - September 2016

ISSN: 2236-269X

DOI: 10.14807/ijmp.v7i3.438

RUTHERFORD, I. (1997). Use of Models to link Indicators of Sustainable Development. In: MODAN, B.; BILHARZ, S. (Eds.) Sustainable Development. Chichester: John Wiley \& Sons Ltda. 